Sprawozdanie $z$ uroczystości wręczenia

Panu Prof. dr. bab. Wactawowi Uruszczakowi

ORDO SANCJJ SJ LVESTRJ PAPAE (Orderu Świętego

Sylwestra Papieża)

podczas sympozjum "Kościót wobec małżeńskich sytuacji

nieregularnycb $w$ świetle posynodalnej adbortacji apostolskiej

Amoris Laetitia Papieża Franciszka", Uniwersytet Papieski

Jana Pawta JJ $w$ Krakowie, Kraków, dnia 17 listopada 2016 r. ${ }^{1}$

\begin{abstract}
The Report on the Conference "The Church Toward Irregular Marriages under Pope Francis' Post-synodic Apostolic Exhortation Amoris Laetitia", John Paul II University in Krakow, November 17 $7^{\text {th }}$ 2016. Papal Order for

Prof. dr dsc. Wacław Uruszczak
\end{abstract}

The symposium was held in Kraków on November $17^{\text {th }}$, and it touched upon the subject of the problem of irregular marriages in light of Pope Francis' post-synodic apostolic exhortation Amoris Laetitia. It was organised by the Faculty of Canon Law of The Pontifical University of John Paul II in Krakow. The participants were greeted by Tomasz Rozkrut (Dean of Canon Law at the Faculty of Canon Law of the Pontifical University of John Paul II). The programme of the conference included the ceremony of bestowing the papal order ORDO SANCTI SILVESTRI PAPAE on Prof. Dr Hab. Wacław Uruszczak. The congratulatory addresses were written by Card. Stanisław Dziwisz (Archbishop of Cracow), Prof. Wojciech Nowak (Rector of the Jagiellonian University), and Prof. Jerzy Pisuliński (Dean of the Faculty of Law and Administration of the Jagiellonian University). The first one was read by the Rev. Prof. Piotr Majer (Head of the Chair of Law on the ecclesiastical mission of teaching

1 Tekst sprawozdania został przesłany także innym redakcjom: „Casus, Studia z Prawa Wyznaniowego”, „Przegląd Prawa Wyznaniowego” oraz środowiskowemu periodykowi w Uniwersytecie Papieskim Jana Pawła II w Krakowie. 
and sanctification), the second one was read by Prof. Dorota Malec (Vice Rector for Development of the Jagiellonian University), and the last one was read by Prof. Barbara Iwańska (Vice Dean for Law studies at the Faculty of Law and Administration of the Jagiellonian University). The introduction to the conference was presented by the Rev. Prof. Józef Stala (Vice Rector for scientific potential and international cooperation of the Pontifical University of John Paul II in Krakow). The laudation speech was given by the Rev. Prof. Jan Maciej Dyduch (the first Rector of the Pontifical University of John Paul II in Krakow). Prof. Wacław Uruszczak addressed the ceremony participants, and then they broke out into two separate sessions. Five papers and one poster session were presented. The papers presented focused on the problem of irregular marriages. The conclusion of the discussion was offered by Bishop Jan Wątroba (Bishop of Rzeszów and Head of the Commission for the Family of the Polish Episcopal Conference). The Rev. Prof. Tomasz Rozkrut closed the symposium.

Key words: Cracow, symposium, marriage irregular situations, Pontifical Order of Pope Saint Sylvester.

Słowa klucze: Kraków, sympozjum, małżeńskie sytuacje nieregularne, Order Papieski Św. Sylwestra.

Wydział Prawa Kanonicznego Uniwersytetu Papieskiego Jana Pawła II w Krakowie (poprzednio jako Instytut Prawa Kanonicznego Papieskiej Akademii Teologicznej w Krakowie) od wielu lat organizuje coroczne spotkania naukowe poświęcone prawu kanonicznemu oraz wyznaniowemu. W bieżącym roku akademickim sympozjum odbyło się w dniu 17 listopada 2016 r., a jego temat brzmiał: „Kościół wobec małżeńskich sytuacji nieregularnych w świetle posynodalnej adhortacji apostolskiej Amoris Laetitia Papieża Franciszka". Obrady miały miejsce w Auli Instytutu Teologicznego Księży Misjonarzy przy ul. Stradomskiej $4 \mathrm{w}$ Krakowie, zapewniającej doskonałe warunki dla przeprowadzania tego rodzaju spotkań naukowych.

Otwarcia sympozjum dokonał ks. prof. dr hab. Tomasz Rozkrut (dziekan Wydziału Prawa Kanonicznego Uniwersytetu Papieskiego Jana Pawła II), który w imieniu organizatorów powitał gości sympozjum. Szczególne słowa przywitania skierowane zostały do prof. dr. hab. Wacława Uruszczaka, kierownika Zakładu Prawa Kościelnego i Wyznaniowego oraz Katedry Historii Państwa i Prawa Polskiego Wydziału Prawa i Administracji Uniwersytetu Jagiellońskiego. Zwracając się do uczestników Sympozjum, ks. prof. dr hab. Tomasz Rozkrut powiedział: „Szanowni Państwo! Trzecie sympozjum zorganizowane przez Wydział Prawa Kanonicznego jest ubogacone wyjątkowym wydarzeniem: wręczeniem orderu papieskiego panu profesorowi Wacławowi Uruszczakowi”.

Tekst adresu Jego Eminencji ks. Stanisława Kardynała Dziwisza, Wielkiego Kanclerza Uniwersytetu Papieskiego Jana Pawła II w Krakowie, odczytał kanclerz Kurii Metropolitalnej ks. prof. dr hab. Piotr Majer (kierownik Katedry Prawa o Kościelnej Misji Nauczania i Uświęcania Uniwersytetu Papieskiego Jana Pawła II w Krakowie). Wspomniano w nim:

Dzisiejsze Sympozjum rozpoczyna się miłym aktem wręczenia Panu Profesorowi dr. hab. Wacławowi Uruszczakowi Orderu św. Sylwestra. Swego czasu pisałem do Księgi Jubileuszowej Pana Profesora: „Osoba, która potrafi dostrzec, gdzie łączą się ze sobą leges i canones cieszy się prestiżem prawdziwego znawcy »obojga praw«”. Powtarzam dziś te słowa, pełne uznania, przy okazji uhonorowania Pana Profesora papieskim odznaczeniem. Dziękuję za wieloletnią pracę naukową na Uniwersytecie Jagiellońskim i Uniwersytecie Papieskim Jana Pawła II i twórczy wkład w ukazywanie wspólnych korzeni i wzajemnego przenikania się prawa kościelnego i prawa polskiego - w historii i w czasach dzisiejszych. 
Słowo wprowadzające w tematykę obrad wygłosił ks. prof. dr hab. Józef Stala (prorektor Uniwersytetu Papieskiego Jana Pawła II w Krakowie ds. potencjalu naukowego i współpracy międzynarodowej). Wskazał w nim na zaangażowanie Kościoła na rzecz rodziny i troskę o nią, jak również na potrzebę dyskusji nad zmianami w prawie i praktyce kanonicznej. Podniósł również, że będąca przedmiotem obrad adhortacja przyczyni się do refleksji w kościołach lokalnych nad zagadnieniami związanymi z małżeństwem.

Następnie ks. prof. dr hab. Tomasz Rozkrut poprosił ks. prof. dr. hab. Jana Macieja Dyducha, pierwszego rektora Uniwersytetu Papieskiego Jana Pawła II w Krakowie, o prezentację sylwetki prof. dr. hab. Wacława Uruszczaka, który przedstawił jego osobę tymi słowami:

Czcigodni i drodzy zebrani!

Dzisiaj będziemy uczestnikami wręczenia „Orderu Św. Sylwestra Papieża” P. Profesorowi Wacławowi Uruszczakowi. Order ten jest bardzo wysokim odznaczeniem papieskim, przyznawanym przez Stolicę Apostolską świeckim, którzy wyróżniają się aktywną działalnością apostolską. Sobór Watykański II naucza, iż apostolstwem jest każda działalność, która zmierza do budowania i rozszerzania Królestwa Chrystusowego na ziemi. Szczególnym rodzajem apostolstwa jest praca naukowo-badawcza i dydaktyczna. Jest ona służbą prawdzie. Jak to nauczał św. Jan Paweł II 8 czerwca 1997 r. w Kolegiacie św. Anny w Krakowie, przemawiając do polskiego „świata nauki”: Mówił, że powołaniem każdego uczonego jest służba prawdzie, jej odkrywanie i przekazywanie innym. Tak rzeczywiście - to uczony szukający, odkrywający i przekazujący prawdę jest apostołem Królestwa Chrystusowego, które jest „Królestwem prawdy i życia, Królestwem świętości i łaski, Królestwem sprawiedliwości, miłości i pokoju”, o czym będzie nam głosić liturgia najbliższej niedzieli w uroczystość Chrystusa Króla i Pana Wszechświata.

Takim uczonym apostołującym poszukiwaniem i przekazywaniem prawdy jest Pan prof. Wacław Uruszczak. Po ukończeniu studiów prawniczych na Uniwersytecie Jagiellońskim w 1969 r. wkroczył na ścieżkę, można powiedzieć, błyskotliwej kariery naukowej. W roku 1975 r. obronił doktorat z historii prawa na Wydziale Prawa UJ. Promotorem dysertacji doktorskiej był prof. Adam Vetulani, znany w Europie ze swoich badań nad Dekretem Gracjana. Nasz Laureat był ostatnim doktorem mistrza Adama Vetulaniego. Od obrony doktoratu Wacław Uruszczak jeszcze bardziej związał się z UJ, uzyskując tam stopień doktora habilitowanego w 1981 r., a kilka lat później w $1990 \mathrm{r}$. tytuł profesora nauk prawnych. Dzisiaj prof. W. Uruszczak jest wybitnym znawcą historii prawa i prawa kościelnego oraz prawa wyznaniowego. Nic więc dziwnego, że prof. Uruszczaka przed laty poproszono o poprowadzenie zajęć w naszej papieskiej uczelni. Najpierw w Instytucie Prawa Kanonicznego Papieskiej Akademii Teologicznej, a potem na Wydziale Prawa Kanonicznego Uniwersytetu Papieskiego Jana Pawła II. Swoją wiedzą, doświadczeniem i postawą kształci i wychowuje przyszłych kanonistów, naszych absolwentów. W ten sposób spełnia rolę Nauczyciela, Mistrza, Świadka i Wychowawcy.

Profesor W. Uruszczak swoimi licznymi publikacjami i wystąpieniami oddziałuje na kształtowanie poprawnych relacji między Kościołem i Państwem w naszej Ojczyźnie. Wkrótce po podpisaniu konkordatu między Stolicą Apostolską a Rzeczpospolitą Polską 
28 lipca 1993 r. nasz Instytut Prawa Kanonicznego urządził sympozjum naukowe, poświęcone roli i znaczeniu konkordatu. Wówczas prof. W. Uruszczak wygłosił znakomity referat pod znamiennym tytułem: O znaczeniu Konkordatu dla Polski - Konkordat nadziei. Zaiste był to „konkordat nadziei” dla zdewastowanego przez „,barbarzyński komunizm” Państwa Polskiego. Swoje wystąpienie prof. Uruszczak zakończył słowami: „Wszyscy powinniśmy bowiem dążyć do budowy cywilizacji miłości w imię prawdziwej solidarności. Z konkordatem wiąże się nadzieja, że cel ten można osiągnąć szybciej”. Podobnie było w roku 1998, po ratyfikacji konkordatu, wówczas na sympozjum także organizowanym przez IPK prof. Uruszczak ukazał konkordat jako „,dokument przyszłości” sprzyjający budowaniu państwa sprawiedliwego, państwa dla wszystkich jego obywateli, w którym panuje ład prawny, moralny i społeczny. Zaiste nasz Laureat to budowniczy mostów między Kościołem i Państwem, budowniczy zgody narodowej tak bardzo potrzebnej także dzisiaj.

Biorąc pod uwagę przywołane zasługi Profesora, jak również te, które nie zostały wyliczone, ze względu na szczupłość czasu, trzeba stwierdzić, że inicjatywa Wydziału Prawa Kanonicznego naszego Uniwersytetu o przyznanie odznaczenia papieskiego Prof. W. Uruszczakowi była bardzo szczęśliwa.

Panie Profesorze, proszę pozwolić, że do Orderu Papieskiego Św. Sylwestra dołączamy wyrazy wdzięczności, gratulacje i najlepsze życzenia: opieki Bożej, zdrowia, dalszych sukcesów w pracy naukowej, dydaktycznej i każdej innej działalności dla dobra Kościoła i naszej Ojczyzny.

Ad multos annos!

Kraków, 17 IX 2016 r. Ks. Jan Dyduch

Po laudacji uroczystego wręczenia i udekorowania laureata orderem, jak i publicznego wręczenia dyplomu papieskiego go przyznającego dokonali ks. prof. dr hab. Jan Dyduch przy udziale ks. prof. dr. hab. Tomasza Rozkruta.

\section{Tekst dyplomu:}

Franciscus Pont. Max.

Precibus nobis adhibitis libenti animo concedentes, e quibus te accepimus de Ecclesiae reique catholicae bono atque incremento bene meritum esse, ut patens gratae nostrae voluntatis testimonium pronamus, te

Wacław Uruszczak

e Archidioecesi Cracoviensi

Equitem Commendatorem Ordinis Sancti Silvestri Papae eligimus, facimus ac renuntiamus, tibique facultatem tribuimus privilegiis omnibus utendi, quae cum hac dignitate sunt coniuncta.

\section{Tekst dyplomu w języku polskim (tłum. prof. dr hab. Wacław Uruszczak):}

\section{Franciszek Papież}

Modlitwami naszymi poruszeni, ochoczym umysłem wiedzeni, przez którego poznaliśmy, że ty dla dobra i rozwoju Kościoła i sprawy katolickiej dobrze się zasłużyłeś, mocą naszej woli niniejsze świadectwo kładziemy, ciebie

Wacława Uruszczaka z Archidiecezji Krakowskiej 
rycerzem komandorem zakonu św. Sylwestra papieża wybieramy, czynimy i ogłaszamy, i tobie prawa korzystania ze wszystkich przywilejów, które z tą godnością są związane, udzielamy.

Następnie prof. dr hab. Dorota Malec (prorektor Uniwersytetu Jagiellońskiego ds. rozwoju) odczytała adres prof. dr. hab. med. Wojciecha Nowaka (rektora Uniwersytetu Jagiellońskiego):

Kraków, 17 listopada 2016 r.

\author{
Szanowny Pan \\ Prof. dr hab. Wacław Uruszczak \\ Kierownik \\ Katedry Historii Prawa Polskiego \\ Wydziału Prawa i Administracji UJ
}

Szanowny Panie Profesorze,

w imieniu własnym, Senatu Uniwersytetu Jagiellońskiego oraz społeczności akademickiej naszej Uczelni składam Panu najserdeczniejsze gratulacje z okazji uhonorowania Orderem Papieskim.

Nagroda to w pełni zasłużona. Działalność Pana Profesora, zarówno na rzecz macierzystego
Wydziału Prawa i Administracji Uniwersytetu Jagiellońskiego, jak i Uniwersytetu Jana Pawła II
w Krakowie oraz w pozostałych obszarach, zasługuje na najwyższe uznanie. Cieszy zatem fakt, że
działania Pana Profesora, poparte ogromnym talentem i pracowitością, zostały dostrzeżone i doce-
nione. Aktywność Pana Profesora w obszarze najbliższych sobie zainteresowań - prawa (w szcze-
gólności prawa kościelnego) i historii, ukazuje, jak bardzo pożądane jest połączenie praktyki dy-
daktyka i prawnika z pasją badacza na najwyższym poziomie, i jak doskonałe mogą być tego efekty.

Szanowny Panie Profesorze, serdecznie gratuluję nagrody i w imieniu społeczności Almae Matris Cracoviensis życzę kolejnych sukcesów tak w życiu zawodowym, jak i osobistym.

Z wyrazami głębokiego szacunku,

Prof. dr hab. med. Wojciech Nowak

Pani Prof. dr hab. Dorota Malec do powyższego adresu dołączyła swoje osobiste słowa, w których wyraziła radość i dumę, że tym odznaczeniem został wyróżniony prof. dr hab. Wacław Uruszczak. Podkreśliła, że dla środowiska historyków prawa, z którego również się wywodzi, profesor Uruszczak stanowi „wzór doskonałości naukowej, poświęcenia dla pracy naukowej”, a także jest człowiekiem „prawym w każdym jego działaniu, w każdym słowie powiedzianym i napisanym".

W dalszej kolejności prof. dr hab. Barbara Iwańska (prodziekan Wydziału Prawa i Administracji Uniwersytetu Jagiellońskiego ds. studiów prawniczych) odczytała Adres Gratulacyjny Społeczności Wydziału Prawa i Administracji Uniwersytetu Jagiellońskiego w Krakowie: 
Adres Gratulacyjny

Społeczności Wydziału Prawa i Administracji

Uniwersytetu Jagiellońskiego w Krakowie:

Wielce Szanowny Pan

Prof. dr hab. Wacław Uruszczak

Czcigodny Panie Profesorze!

Z okazji uhonorowania Pana Profesora przez Jego Świątobliwość Ojca Świętego Franciszka zaszczytnym i prestiżowym Orderem Rycerskim Świętego Sylwestra, proszę przyjąć od całej Społeczności Wydziału Prawa i Administracji Uniwersytetu Jagiellońskiego najserdeczniejsze gratulacje i słowa najwyższego uznania.

Jesteśmy zaszczyceni, że Pan Profesor, Członek Naszej Społeczności, otrzymuje tak wysokie wyróżnienie, podkreślające Pańskie wybitne dokonania naukowe. Życzymy Panu Profesorowi dalszych sukcesów w każdej sferze aktywności, jak najlepszego zdrowia i pokoju ducha.

Ad multos annos!

Prof. dr hab. Jerzy Pisuliński

Dziekan Wydziału Prawa i Administracji UJ

Dano w Krakowie, dnia 17 listopada 2016 r.

Prof. dr hab. Barbara Iwańska (prodziekan Wydziału Prawa i Administracji UJ ds. studiów prawniczych) po odczytaniu adresu gratulacyjnego również dołączyła swoje własne wyrazy uznania dla laureata.

Następnie swoje przemówienie wygłosił prof. dr hab. Wacław Uruszczak:

Czcigodny Księże Rektorze, Dostojny Księże Dziekanie, stości!

Czcigodni Księża, Panie i Panowie Profesorowie, Drodzy zebrani świadkowie dzisiejszej uroczy-

Wręczenie mi dzisiaj orderu papieskiego stanowi dla mnie dużą niespodziankę. Nigdy, nawet w najśmielszych marzeniach tego nie oczekiwałem. Jest to bez wątpienia dla mnie wielki honor i zaszczyt. Z mojej strony należą się podziękowania tym wszystkim osobom, które przyczyniły się do mojego wyróżnienia. Dziękuję w pierwszej kolejności Jego Świątobliwości Ojcu Świętemu Franciszkowi, dziękuję Waszej Eminencji Kardynałowi Stanisławowi Dziwiszowi, metropolicie krakowskiemu, dziękuję Magnificencji Rektorowi Uniwersytetu Papieskiego, dziękuję księdzu dziekanowi Tomaszowi Rozkrutowi, dziękuję bardzo serdecznie księdzu Rektorowi Janowi Dyduchowi za przepiękną laudację. Z pewnością krąg osób, którym należą się moje podziękowania jest większy. Wszystkim osobom zaangażowanym w tę sprawę niniejszym bardzo serdecznie dziękuję.

Dziękuję także przedstawicielom władz UJ - pani prorektor Dorocie Malec i pani prodziekan Barbarze Iwańskiej, za przybycie, za odczytane adresy JM Rektora prof. Wojciecha Nowaka i dziekana prof. Jerzego Pisulińskiego, dziękuję wszystkim moim kolegom, współpracownikom, przyjaciołom, członkom mojej rodziny.

W tym roku we wrześniu ukończyłem 70 lat życia. Mam za sobą 47 lat pracy w Uniwersytecie Jagiellońskim. Do pracy w tej uczelni zachęcił i zaangażował mnie profesor Adam Vetulani, wybitny historyk prawa i kanonista. W tym roku we wrześniu minęła 40 rocznica jego śmierci. On to w latach 1928-1946 z przerwą w okresie okupacji niemieckiej kierował Katedrą Prawa Kościelnego; w 1946 r. objął Katedrę Historii Prawa Polskiego, którą kierował do 1970 r. Kiedy Katedra Prawa Kościelnego została zlikwidowana w 1950 r., Adam Vetulani nie zaprzestał prowadzenia badań naukowych w zakresie prawa kanonicznego i kanonistyki, osiągając znakomite wyniki na arenie międzynarodowej. 
Ja nie pochodzę z rodziny profesorskiej. Mój ojciec i dziadek byli rzemieślnikami w artystycznej dziedzinie brązownictwa. Moją uniwersytecką karierę zawdzięczam w poważnej części Adamowi Vetulaniemu. To on, pod koniec swojego życia, a na początku mojej naukowej drogi, wprowadził mnie w badania nad średniowiecznym prawem kanonicznym. Rad jestem, że mogłem te badania z nie najgorszym skutkiem kontynuować. W 1990 r. z inicjatywy profesora Wojciecha Marii Bartla, dziekana Wydziału Prawa, udało się reaktywować Katedrę Prawa Kościelnego, co pozostaje jego wiekopomną zasługą. Po niespodziewanej śmierci prof. Bartla w 1992 r. przejąłem kierownictwo tej Katedry. Udało mi się umocnić jej pozycję, z pewnością dzięki pomocy moich młodych współpracowników, przy życzliwości władz wydziału, zwłaszcza w okresie ostatniej kadencji. Serdecznie im wszystkim za to dziękuję. Obok Katedry Prawa Kościelnego i Wyznaniowego kierowałem od 1999 r., i tak jest jeszcze dziś, Katedrą Historii Prawa Polskiego.

Jeśli udało mi się coś osiągnąć, to zawdzięczam to oczywiście Bożej Opatrzności i, ale także mojej rodzinie, w szczególności mojej małżonce Barbarze. W tym roku minęło 45 lat od naszego ślubu w Kolegiacie Akademickiej św. Anny w Krakowie (szafirowe gody). Celebransem naszego ślubu był ks. Adam Boniecki. Za te 45 lat wspólnego życia, na dobre i na złe, bardzo serdecznie Ci, Basiu, dziękuję!

Ale równocześnie dziękuję moim dzieciom, Michałowi i Oli, a także nieobecnemu wśród nas Adamowi. Oto dorobek mojego życia. Owszem, mam w tym dorobku wiele już książek i artykułów, czy innych jeszcze publikacji. Ale tak naprawdę to dopiero czas pokaże, co z tego dorobku jest prawdziwie wartościowe.

Podziękowania, nagrody czy odznaczenia są zawsze sympatyczne. Ale pracując naukowo w kanonistyce, czy podejmując różne inne czynności, raczej nie oczekiwałem tego. Parafrazując Ewangelię św. Łukasza, rozdział 17, powiem: „Sługą nieużytecznym jestem; zrobiłem tylko to, co powinienem wykonać".

Jeszcze raz wszystkim za to piękne wyróżnienie dziękuję.

Ks. prof. dr hab. Tomasz Rozkrut podziękował prof. dr. hab. Wacławowi Uruszczakowi za słowa skierowane do uczestników sympozjum, po czym poprosił dr Aleksandrę Brzemię-Bonarek (Uniwersytet Papieski Jana Pawła II w Krakowie) do moderowania pierwszej z dwóch sesji sympozjum. W tej części wygłoszono trzy referaty. Jako pierwszy wystąpił ks. prof. dr hab. Pawel Bortkiewicz (Uniwersytet im. Adama Mickiewicza w Poznaniu) z referatem Prawo stopniowości a stopniowalność prawa w odniesieniu do małżeństwa i rodziny. Przypomniał on o prawie stopniowości, które ma głębokie znaczenie teologiczne i praktyczne, a zgodnie z którym człowiek czyni dobro moralne odpowiednio do swojego rozwoju. Wskazał na odróżnienie prawa stopniowości od stopniowalności prawa oraz przeprowadził analizę krytyczną wybranych twierdzeń adhortacji Amoris Laetitia, w szczególności „,sprawdzonej wierności”, w tym w świetle poglądów św. Augustyna i św. Tomasza z Akwinu.

Następnie swój odczyt Od kiedy zaczyna się matżeństwo? Problem uważnienia w zawiązu sytuacji nieregularnych zaprezentował ks. dr hab. Leszek Adamowicz, prof. KUL (Katolicki Uniwersytet Lubelski). W ramach tego referatu przedstawiono w zarysie stan polskiego prawa w zakresie chwili powstawania małżeństwa oraz skonfrontowano go z regulacjami prawa kanonicznego. Omówiono również kwestie uważnienia w zawiązku i jego warunków w sytuacjach nieregularnych.

Ostatnie wystąpienie w tej części należało do ks. dr. Andrzeja Wójcika (Uniwersytet Papieski Jana Pawła II w Krakowie), który zaprezentował temat Czy sytuacje nieregularne moga zawierać elementy prawdziwego matżeństwa?. W ramach tego wystąpienia wskazano przede wszystkim na stanowisko przedmiotowej adhortacji w sprawie możliwości istnienia elementów prawdziwego małżeństwa w sytuacjach nieregularnych. Prelegent podkreślił naturalną dążność miłosnego związku mężczyzny i kobiety do kon-

Kronika naukowa - Chronicle of scbolarly events 
sensu małżeńskiego oraz błędność stanowiska traktującego małżeństwo w kategoriach heteronomiczności prawa. Następnie nad referatami przeprowadzono dyskusję z udziałem prelegentów, po której nastąpiła przerwa, w jej trakcie uczestnicy sympozjum mogli skorzystać z poczęstunku.

Ponadto w trakcie przerwy prezentowana była sesja posterowa, do zapoznania z którą zachęcała dr Aleksandra Brzemia-Bonarek. Po przerwie wznowiono obrady (część drugą), które prowadził dr Tomasz Szeląg (Uniwersytet Pedagogiczny w Krakowie). Wygłoszone zostały dwa referaty. Jako pierwszy wystąpił ks. prof. dr hab. Zbigniew Janczewski (Uniwersytet Kardynała Stefana Wyszyńskiego w Warszawie) z tematem Dopuszczenie do sakramentów wtajemniczenia osoby w nieregularnej sytuacji matżeńskiej. W ramach tego przedłożenia przeprowadzono analizę przesłanek udzielania sakramentów, zarówno w sytuacji zwyczajnej, jak i nadzwyczajnej, w kontekście nieregularnej sytuacji małżeńskiej. Dowodzono, iż nie każda sytuacja nieregularna wiąże się z grzechem ciężkim, jak również wskazano na zmiany w podejściu do przesłanek udzielania sakramentów w ujęciu historycznym.

Ostatni referat zaprezentował ks. dr hab. Piotr Steczkowski, prof. UR (Uniwersytet Rzeszowski), Dopuszczenie do Komunii Świętej osób żyjacych po matżeńsku bez matżeństwa - norma czy subiektywna ocena?. Prelegent przedstawił warunki określone w prawie kanonicznym dopuszczenia do Komunii Świętej oraz omówił zgłaszane wątpliwości dotyczące pojęcia czynu wewnętrznie złego w kontekście sytuacji nieregularnych, pojawiające się na tle wykładni adhortacji Amoris Laetitia. Referent skonstatował, że właściwie interpretowana jej treść nie prowadzi do zmiany doktryny, lecz jej postanowienia stanowią kontynuację nauczania Kościoła, potencjalnym zagrożeniem zaś może być wyłącznie brak precyzyjności samego tekstu, który bez drobiazgowej wykładni może rodzić wątpliwości.

Po przeprowadzeniu dyskusji podsumowania obrad dokonał Jego Eminencja Jan Wątroba, biskup rzeszowski, przewodniczący Rady ds. rodziny Konferencji Episkopatu Polski. Następnie ks. prof. dr hab. Tomasz Rozkrut podziękował prelegentom oraz uczestnikom sympozjum, jak również gospodarzom i osobom organizującym obrady. Wskazał także na prowadzone w Stolicy Apostolskiej prace nad zmodyfikowaniem nauczania prawa kanonicznego Zamykając obrady, ks. prof. dr hab. Tomasz Rozkrut jeszcze raz pogratulował prof. dr. hab. Wacławowi Uruszczakowi otrzymania zaszczytnego papieskiego odznaczenia.

Sympozjum „Kościół wobec małżeńskich sytuacji nieregularnych w świetle posynodalnej adhortacji apostolskiej Amoris Laetitia Papieża Franciszka" pozostanie w pamięci jego uczestników jako kolejne udane spotkanie naukowe osób zajmujących się prawem kanonicznym. Organizatorom należy się w tym zakresie najwyższe uznanie i wyrazy podziękowania. Tegoroczna konferencja będzie szczególnie zapamiętana z uwagi na uroczystość wręczenia prof. dr. hab. Wacławowi Uruszczakowi najwyższego odznaczenia papieskiego przyznawanego osobom świeckim, jakim jest Order Świętego Sylwestra Papieża - ORDO SANCTI SILVESTRI PAPAE - w klasie komandorskiej. 
Warto dodać, iż w dniu 17 stycznia 2017 r. Ars Legis Stowarzyszenie im. Św. Ivo Helory - patrona prawników - zorganizowało w Klubie Adwokata w Krakowie spotkanie z profesorem Wacławem Uruszczakiem. Podczas spotkania liczne dokonania naukowe i organizatorskie profesora przedstawił Zdzisław Zarzycki. Pełny tekst wystąpienia zostanie opublikowany w numerze specjalnym czasopisma „Palestra” (rocznik 2017).

Pracownicy i doktoranci Zakładu Prawa Kościelnego i Wyznaniowego 